\title{
The role of the agrofood industry in regional development in Spain: consequences of integration into the EC
}

\author{
J. M. GIL and L. PÉREZ Y PÉREZ \\ Unidad de Economía Agraria, SIA, Diputación General de Aragón, Apdo. 727, 50080 Zaragoza, Spain
}

\begin{abstract}
This paper analyses the contribution of food processing industries in Spanish regional development. The agrofood industry is one of the most important industrial sectors in Spain and, in recent years, it has been an important component in the development of rural áreas. Factors affecting the location of food industries and changes taking place after accession to the European Community (EC) are analysed. The entry of Spain into the EC has brought about a change in the food industries' relative growth in Spanish regions. Before joining the $\mathrm{EC}$, the agrofood industry experienced the highest growth in the most developed regions, cióse to big consumption markets. After die Spanish entry into the EC, more investments have been taking place in regions where the rural sector plays an important role, trying to compénsate for farmers' losses owing to decreasing agncultural prices as a consequence of the Common Agricultural Policy reform.
\end{abstract}

Keywords: Agrofood industry; regional development; Spanish entry into the EC; factor and cluster analysis; regression analysis; multicollinearity.

\section{Introduction}

The agrofood industry is one of the most important industrial sectors in Spain. Total gross production was around 5.7 billion pesetas in 1990. This represents approxi-mately $20 \%$ of total industrial production. The Gross Valué Added (GVA) generated by food processing industries (FPI) was 1.5 billion pesetas (around 14.5\% of the GVA generated by the whole industrial sector). It is the second most important industrial sector after energy (INE 1993). From a historical perspective, the impact of the two oil crises during the 1970s on the FPI has been less important than in other sectors of the Spanish economy (Gil and Pérez y Pérez 1992).

Traditionally the agrofood industry had been cióse to agricultural áreas. Migration to urban áreas, changing consumptíon patterns (new consumers looking for better quality and more elabórate producís), less expensive transport costs of raw agricultural commoditíes in comparison to elabórate producís and the existence of more powerful distribution chains, among other factors, shifted the location of agrofood industries from rural to urban áreas. As a consequence, less developed Spanish regions (where agricultural and livestock production is more important) were losing a sig-nificant part of the valué added agricultural producís. The picture has been changing since Spain joined the EC in 1986. This period has also been characterized by a general economic development. More resources have been devoted (both national and from the EC) to promote rural development. Some investments have been made in food industries located in regions with an important agricultural sector trying 
to maintain farmers' income which, in real terms, has decreased due to the Common Agricultural Policy (CAP) reform.

There are several general studies about the agrofood industry in Spain at the national level Qordana ad Pulgar 1980, Jordana 1983, De Haro and Titos 1983, Fernández and Ruesga 1984, Bueno and Ramos 1989). There are also specific studies that analyse the relative importance of this sector in difFerent regions: Galicia (Sequeiros 1983), País Vasco (Caja Laboral Popular 1987), Castilla y León (Rodríguez-Zúñiga et al. 1982), Madrid (Sanz 1989) and Rioja, Navarra y Aragón (Rapún Gárate and Pérez y Pérez 1990). All of these studies describe food industries at national or regional levéis and consider their main characteristics, problems and future prospects. Gil and Pérez y Pérez (1992) analysed the relative importance of the agrofood industry in Spanish regions and its relative growth over the period 1981- 88 and outlined factors affecting the regional location of agrofood industries.

The objective of this paper is to analyse the relationship between the agrofood industry and regional development in Spain and to evalúate the impact of the Spanish entry into the EC on the relative growth of such industries at the regional level. The paper is organized as follows. In section 2 some recent developments of the Spanish agrofood industry and its regional importance are analysed. A classification of Spanish regions based on their agrofood development is undertaken in section 3. Factors affecting the location of the agrofood industry are specified in section 4. Regression techniques are used to estímate the relative impact of such factors distin-guishing before and after Spanish accession to the EC. Finally, some conclusions are outlined.

\section{The agrofood industry in Spain: its regional importance}

The relative importance of food processing industries is not homogeneous across Spanish regions. The main structural indicators associated with the agrofood industry in each región are shown in table 1 (location of regions is shown in figure 1 ).

First, only two regions (Cataluña and Andalucía) generated $40 \%$ of the total FPI gross valué added (20.1\% and $18.6 \%$, respectively). The second important group is made up by three regions that generated around $25 \%$ of the total gross valué added (Comunidad Valenciana, 9.7\%; Madrid, 8.9\%; and Castilla-León, 7.9\%). The valué added generated by the agrofood industry reached 1.5 billion pesetas in 1990. Gil and Pérez y Pérez (1992) showed that, between 1978 and 1988, the agrofood industry gross valué added index was always above that for the industrial sector, indicating that food processing industries have been more efficient in reducing production costs.

Employment distribution in the different regions showed a similar pattern to gross value added. In this case, Cataluña and Andalucía were the most important regions accounting for 35\% of total FPI employment. Another 33\% of employers are distrib-uted among Comunidad Valenciana (10\%), Castilla-León (8.4\%), Madrid (7.4\%) and Galicia (7.1\%). Spanish FPI employed 361,485 workers (around 17\% of the whole industrial sector employment). Between 1978 and $1990 \mathrm{FPI}$ employment has been reduced by $11 \%$, and the number of factories has been diminished by $20 \%$. As a consequence, the average size of a FPI factory has slightly increased from 7.7 workers, in 1978, to 8.7 workers, in 1990. The average size is still very low and it is one of the most important factors impeding the competitiveness of this sector in Europe. 
Table 1. Food processing industry valué added, employment and labour productivity in Spanish regions (1990).

\begin{tabular}{lcclc}
\hline & $\begin{array}{l}\text { FPI gross valué } \\
\text { added (million } \\
\text { pesetas) }\end{array}$ & $\begin{array}{l}\text { FPI employment } \\
\text { (A) }\end{array}$ & $\begin{array}{l}\text { FPI labour } \\
\text { productivity } \\
\text { (million pesetas) }\end{array}$ & $\begin{array}{l}\text { FPI GVAI Industrial } \\
\text { GVA (\%) }\end{array}$ \\
\hline Andalucía & 290,862 & 63,413 & 4.59 & 31.36 \\
Aragón & 47,576 & 11,495 & 4.14 & 10.25 \\
Asturias & 37,766 & 7,458 & 5.06 & 9.94 \\
Baleares & 20,804 & 5,927 & 3.51 & 20.51 \\
Canarias & 58,305 & 10,700 & 5.45 & 40.86 \\
Cantabria & 25,210 & 6,822 & 3.69 & 15.63 \\
Castilla-León & 124,173 & 30,198 & 4.11 & 17.61 \\
Castilla-La Mancha & 51,641 & 16,923 & 3.05 & 11.40 \\
Cataluña & 314,296 & 62,5545 & 5.02 & 11.58 \\
C. Valenciana & 151,772 & 36,400 & 4.17 & 14.10 \\
Extremadura & 21,700 & 7,769 & 2.79 & 14.22 \\
Galicia & 93,633 & 25,517 & 3.67 & 16.23 \\
Madrid & 139,680 & 26,684 & 5.23 & 10.50 \\
Murcia & 52,641 & 19,317 & 2.72 & 25.65 \\
Navarra & 38,697 & 11,121 & 3.48 & 13.77 \\
País Vasco & 54,970 & 13,004 & 4.23 & 5.50 \\
Rioja & 39,431 & 6,173 & 6.39 & 36.12 \\
Spain & $1,563,157$ & 361,485 & 4.32 & 14.50 \\
\hline Sain & & & & \\
\hline
\end{tabular}

Sourcr. Instituto Nacional de Estadística (severalyeaTS). Encuesta Industrial.

A regional indicator of productivity has been obtained by combining gross valué added and employment data. Results are shown in column 3 of table 1. The national average was 4.32 million pesetas/employee, in 1990. Productivity in Murcia and Extremadura were well under average (2.72 and 2.79 million pesetas/employee, respectively). On the other hand, the highest productivity is found in Rioja (6.39 million pesetas/employee). Also, Asturias, Canarias, Cataluña and Madrid were above average. Aragón, Castilla-León, Comunidad Valenciana and País Vasco were around average.

The last column in table 1 shows the regional importance of FPI in comparison with the whole industrial sector in each región. FPI generated around 14.5\% of total industrial gross valué added at the national level. Big differences have been found when analysing regional figures. In Canarias and Rioja the agrofood industry was the most important sector. It represented, in 1990, $40.86 \%$ and $36.12 \%$, respectively, of regional industrial gross valué added, although their contributions to the national total were quite low (3.7\% and $2.5 \%$, respectively). Rioja is a particular case, as will be shown below, exhibiting a strong relationship between agricultural sector and agrofood industry.

FPI also played an important role in the regional economies of Andalucía, Murcia and Baleares (31.36\%, 25.65\% and 20.51\%, respectively). On the other hand, País Vasco (5.50\%), Asturias (9.94\%), Aragón (10.25\%) and Madrid $(10.50 \%)$ were well under the national average. However, these figures do not mean that food industries are not important in those regions. For example, in Aragón, FPI was the second largest industrial sector both in production and in employment levéis.

\section{Linkages among agricultura, food processing industries and economic development in Spanish regions}

Important differences exist among Spanish regions when considering agrofood industrial development. In this section, an atternpt to classify regions is carried out accord-ing to the relative importance of the agricultural sector, food processing industries and the degree of economic development in each región.

The following variables have been considered to make a regional typology.

All data refer to 1989; data source is INE (1994). Factor and cluster analyses have been used to classify regions. 
The objective of using factor analysis was to reduce information from original variables in a lower number of factors (artificial variables). Relationships between regions and original variables have been established using these factors. Cluster analysis was used to classiy regions in homogeneous groups, a priori unknown, in such a way that distances among regions within a group were lower than distances among regions from diñerent groups. In this paper, regions have been classified based on the information from the first two factors derived from factor analysis.

Results from factor analysis indicated that the first two factors explained $85.5 \%$ of the total variance. Factor 1 explained $53 \%$ of the total variance. It was significantly and positively correlated with variables related to the importance of the agricultural sector in each región (GVAGRr and EMPAGR,.) and negatively correlated with regional per capita income $\left(\mathrm{I}_{\mathrm{r}}\right)$. So, this factor allowed the división of regions into two main groups. First, regions with low per capita income level and important agricultural sectors. Second, regions with high income level and agriculture playing a residual role.

Factor 2 explained $33 \%$ of the total variance. It was significantly and positively correlated with variables referring to the agrofood industry (GVAFPIr and EMPFPIr). Also, a positive correlation, although less significant, was found with regional per capita income. Thus, this factor considered regions where the agrofood industry played an important role within the regional economy and where per capita income was abo ve average.

Figure 1 combined results from factor and cluster analysis. Regions within the same group are drawn with the same pattern. The 17 regions have been classified in seven

\section{Table 2. Correlation matrix between original variables and factors 1 and 2.}

$\begin{array}{lrr} & \text { Factor 1 } & \text { Factor 2 } \\ \text { GVAGR* } & 0.97 & 0.03 \\ \text { GVAFPP } & 0.33 & 0.82 \\ \text { EMPAGR" } & 0.89 & -0.25 \\ \text { EMPFP|* } & -0.86 & 0.83 \\ \text { Income } & -0.80 & 0.46 \\ \text { \% of total variance } & 0.53 & 0.33 \\ & & \\ \text { * GVAGR: Agriculture's gross valué added over total gross valué added GVAFPI: Food processing } \\ \text { industries' gross valué added over total gross valué added EMPAGR: Agriculture's employment over } \\ \text { total employment EMPFPI: Food processing industries' employment over total employment }\end{array}$

homogeneous groups. Table 3 shows average valúes of original variables for each group and national averages.

Aragón, Asturias, Canarias and Comunidad Valenciana formed the first group. The average valúes of the original variables in these regions were quite similar to the national average. Valúes from agricultural and agrofood industry variables were slightly below the national average and per capita income was above.

Group II was comprised of Galicia and Extremadura. These are two of the poorest regions in Spain. Per capita income was below the national average and agriculture still played an important role in their regional economy. However, food processing industries had not been well developed and there existed a loss in valué added.

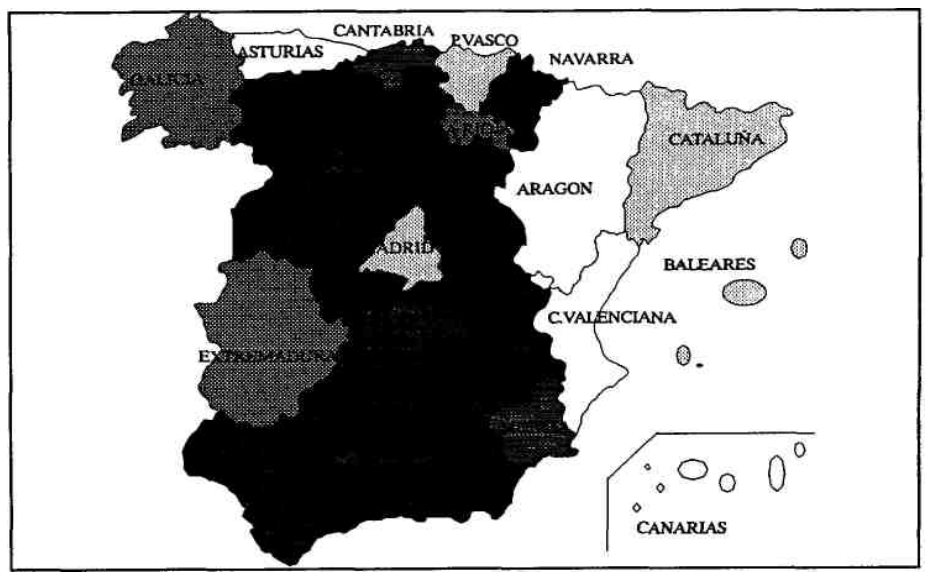


Table 3. Average valúes of original variables in groups generated by cluster analysis.

\begin{tabular}{|c|c|c|c|c|c|}
\hline Región & GVAGR & GVAFPI & EMPAGR & EMPFPI & Income \\
\hline $\begin{array}{l}\text { I } \\
\text { Aragón } \\
\text { Asturias } \\
\text { Canarias } \\
\text { C. Valencia }\end{array}$ & 4.88 & 4.08 & 11.69 & 2.87 & 813.10 \\
\hline $\begin{array}{l}\text { II } \\
\text { Extremadur } \\
\text { Galicia }\end{array}$ & 11.54 & 4.67 & 29.17 & 3.01 & 630.95 \\
\hline $\begin{array}{l}\text { III } \\
\text { Madrid País } \\
\text { Vasco } \\
\text { Baleares } \\
\text { Cataluña }\end{array}$ & 1.76 & 3.18 & 3.28 & 2.56 & 958.5 \\
\hline $\begin{array}{l}\text { IV } \\
\text { Andalucía C } \\
\text { Castilla-La I }\end{array}$ & 9.91 & 5.81 & 18.24 & 4.12 & 676.10 \\
\hline $\begin{array}{l}\text { V } \\
\text { Murcia } \\
\text { Cantabria }\end{array}$ & 8.61 & 5.72 & 14.40 & 5.78 & 767.2 \\
\hline VI Navarra & 6.09 & 7.47 & 9.88 & 8.42 & 955.64 \\
\hline $\begin{array}{l}\text { VII } \\
\text { La Rioja }\end{array}$ & 8.97 & 23.01 & 12.18 & 6.82 & 906.87 \\
\hline Spain & 5.14 & 4.79 & 11.79 & 3.36 & 788.04 \\
\hline
\end{tabular}

Group III was made up of Madrid, País Vasco, Baleares and Cataluña, the most developed regions in Spain. The main characteristics were high per capita income levéis but with an agricultural sector and an agrofood industry of relative importance only in their regional economies.

Andalucía, Castilla-La Mancha and Castilla-León formed group IV. The relative importance of the agricultural sector in these regions was very high, as in group II. Per capita income was also below national average. However, food processing industries played a more important role than in group II (GVAFPI and EMPFPI valúes were around average).

Murcia and Cantabria (group V) presented similar characteristics to regions in group IV, but per capita income was higher, the agricultural sector had less relative significance and the agrofood industry was more important in terms of employment.

The two remaining groups comprised only one región each. Navarra (group VI) had an income level above the national average. The role of the agricultural sector in its economy was not very high. However, the agrofood industry played an important role in both employment and gross valué added levéis.

For Rioja (group VII) an important agrofood industry has been developed based on its agricultural sector. Most of the valué added generated by food processing industries remained in the región. Valúes for all variables were higher than national averages. 


\section{The Spanish accession to the EG and the location of agrofood industries}

The objective is to determine the effect of location on the development of agrofood industries in each región and to evalúate the impact of the Spanish accession to the EC. As a first step, the shift-share framework has bpen applied to production data in agrofood industries. Two periods of the same length have been distinguished: 1981-85 and 1986-90 (before and after Spanish accession to the EC). Production changes between the two periods have been broken down in the following way:

$\wedge_{A R}--P A R=\wedge A R 7 N+-P A R(7 A N-7 N)+{ }^{\wedge} A R\left({ }^{\wedge} A R-{ }^{A N N}\right)$

where, ÍARY $=0>0$ is the regional agrofood industry production in year $i$ (constant valúes), $7 \sim N$ is the real growth of the whole industrial sector at the national level, TAN is the real growth of the agrofood industry at national level, and TAR is the real growth of the agrofood industry at regional level.

The three components of equation (1) are: the national share, the structural com-ponent (or proportional shift) and the competítive component (or difíerential shift), respectively. Results from this analysis for both periods are gathered in tables 4 and 5. Total production change in the agrofood industry, in each región, is shown in the first column for both periods. The differences are quite significant. The period 1981-85 is characterized by consequences of the second oil crisis and a recession period. Most regions diminished their production levéis during this period. In the second period, 1986-90, characterized by an expansión of the Spanish economy and the accession to the EC, all regions, except Rioja, increased their production level in the agrofood industry in real terms. National change in production was 1.1 billion pesetas. Cataluña accounted for one-third of total national change.

The second column shows what the growth would have been if the agrofood industry in each región had grown at the same rate as the whole industrial sector. Between 1981 and 1985, production growth was negative for all regions while in the 1986-90 period the growth was positive. The reverse happens in column 3, which reflects the growth that would have taken place if food processing industries had grown at the national rate. Both columns indícate that the impact of economic cycles on food processing industries is less important than in other sectors of the Spanish economy. During a period of crisis, the growth rate of the food processing industries is higher than for other industrial sectors while for expansión periods the situation is the reverse.

Finally, the fourth column of both tables, the most relevant in this study, shows the effects of location advantage in each región. In the first period (table 4), Andalucía, Castilla-León and Castilla-La Mancha, which formed a homogeneous group as a result of the cluster analysis, showed a locational advantage. Also, large consumption áreas were a factor in the location of the agrofood industry. Agrofood industries in Cataluña and Madrid experienced a significant positive growth. After accession to the EC, the overall picture changed. Mediterranean regions (Cataluña, C. Valenciana and Murcia) have been more competitive than other regions (table 5). Growth of the processing industries in these regions was above the national rate. In Rioja, where the agrofood industry was quite important within its regional economy, its growth was below the national rate. 
Table 4. Shift-share analysis for food processing industries between 1981 and 1985

(million pesetas).

\begin{tabular}{lcccc}
\hline & \multicolumn{2}{l}{ Total production } & & \\
Regions & change & National share & Proportional shift & Differential shift \\
\hline Andalucía & 94,200 & $-3,997$ & 32,772 & 65,425 \\
Aragón & 7,383 & -756 & 6,196 & 1,943 \\
Asturias & $-4,944$ & -549 & 4,498 & $-8,894$ \\
Baleares & $-5,905$ & -266 & 2,178 & $-7,817$ \\
Canarias & 471 & -494 & 4,049 & $-3,084$ \\
Cantabria & 9,905 & -373 & 3,055 & 7,222 \\
Castilla-León & 14,276 & $-1,938$ & 15,893 & $-26,377$ \\
Castilla-La Mancha & $-17,598$ & $-1,219$ & 9,998 & 45,325 \\
Cataluña & 75,962 & $-4,255$ & 34,892 & $-5,133$ \\
C. Valenciana & 7,781 & $-1,793$ & 14,707 & $-8,392$ \\
Extremadura & $-5,231$ & -439 & 3,601 & $-36,934$ \\
Galicia & $-25,976$ & $-1,522$ & 12,480 & 16,343 \\
Madrid & 27,309 & $-1,523$ & $-4,453$ \\
Murcia & -45 & -612 & 12,489 & $-13,973$ \\
Navarra & $-9,500$ & -621 & 5,020 & $-32,239$ \\
País Vasco & $-27,741$ & $-1,041$ & 5,094 & 7,499 \\
Rioja & 11,835 & -602 & 8,539 & 4,938 \\
\hline
\end{tabular}

Source-. Instituto Nacional de Estadística (severalyears). Contabilidad Regional.

Although the shift-share framework has some limitations and it is not possible to predict future behaviour, results from this analysis are consistent with those obtained earlier about the agrofood industrial location.

Table 5. Shift-share analysis for food processing industries between 1986 and 1990

(million pesetas).

\begin{tabular}{|c|c|c|c|c|}
\hline \multirow[b]{2}{*}{ Regions } & \multicolumn{2}{|c|}{ Total production } & \multirow[b]{2}{*}{ Proportional shift } & \multirow[b]{2}{*}{ Differential shift } \\
\hline & change & National share & & \\
\hline Andalucía & 156,264 & 296,644 & $-58,971$ & $-81,409$ \\
\hline Aragón & 29,940 & 52,622 & $-10,461$ & $-12,220$ \\
\hline Asturias & 34,404 & 37,784 & $-6,915$ & 6,535 \\
\hline Baleares & 23,924 & 15,676 & $-3,116$ & 11,365 \\
\hline Canarias & 37,564 & 32,941 & $-6,549$ & 11,172 \\
\hline Cantabria & 22,252 & 28,028 & $-5,572$ & -204 \\
\hline Castilla-León & 110,673 & 133,431 & $-26,525$ & 3,768 \\
\hline Castilla-La Mancha & 21,937 & 75,119 & $-14,933$ & $-38,249$ \\
\hline Cataluña & 315,325 & 307,762 & $-61,182$ & 68,744 \\
\hline C. Valenciana & 120,359 & 121,671 & $-24,188$ & 22,876 \\
\hline Extremadura & 8,100 & 27,420 & $-5,451$ & $-31,869$ \\
\hline Galicia & 91,991 & 92,433 & $-18,375$ & 17,934 \\
\hline Madrid & 67,126 & 110,194 & $-21,906$ & $-21,162$ \\
\hline Murcia & 76,122 & 40,638 & $-8,079$ & 43,563 \\
\hline Navarra & 36,835 & 38,095 & $-7,573$ & 6,313 \\
\hline País Vasco & 35,581 & 60,931 & $-12,113$ & $-12,238$ \\
\hline Rioja & $-6,360$ & 43,917 & $-8,730$ & $-41,546$ \\
\hline
\end{tabular}

Source: Instituto Nacional de Estadística (seoeralycars). Contabilidad Regional.

It is clear that some changes have been taking place since the entry of Spain into the EC. The differential shift from the shift-share analysis has been used as the dependeht variable of the locational process in a model (one for each period) which initially considered the foUowing factors (the superindex $t$ refers to year 1985, in the first period, and 1990, in the second; the superindex 0 refers to years 1981 and 1986, respectively): 
Most of these factors have been considered in relative terms (compared with the national average) and, in some cases, as a variation during the periods 1981-85 and 1986-90. The same approach was followed by Terrasi (1984) in the Italian case. Two regions have been excluded from the analysis (Baleares and Canarias) as their inclusión distorted results because of their specific economic and location conditions.

Gil and Pérez y Pérez (1992) used the same variables to analyse factors explaining die location of agrofood industries in Spain between 1981 and 1988. However, they found problems of severe multicollinearity among these factors when including them as independent variables in a regression framework. In this study, to overeóme the technical problem of multicollinearity, principal components analysis has been used. The objective was to replace interrelated variables by a lower number of uncorrelated principal components.

First, the eight variables were considered for principal components analysis. Then, independent variables were classified in three groups. The first group deals with the relative importance of the agricultural sector in each región: agricultural production and agricultural production variation. The second group was related to the agrofood industry: wages, wage variation and labour cost per employee. The third group referred to actual and potential regional economic development: per capita income, market potential and food wholesaler and retailer licences. A composite variable has been considered for each group. Correlations between original variables and components are shown in table 6 . As there were only a few variables, components explained a

large percentage of variance. However, interpretation of the components changes over time. For instance, in the first period (1981-85) C2 is positively correlated with wage variation; in the second period, C2 is highly and positively correlated with labour cost per employee. A similar case is represented by $\mathrm{Cl}$. The correlation with agricultural production variation is positive, in the first period, and negative, in the second. Correlations between original variables and $\mathrm{C} 3$ are similar in both periods. In any case, careful attention must be paid to correlation signs in order to adequately inter-pret results from regressions.

As a final step, one equation for each period has been estimated to explain the locational advantage of Spanish regions for the food industries. The dependent variable, as it was mentioned above, was the differential shift obtained in the previous shift-share analysis. Exogenous variables were composite variables generated by principal components analysis. Estimated results are presented in table 7.

Before joining the $\mathrm{EC}$, the three composite variables explained almost two-thirds of the relative growth of food processing industries in each región. A dummy variable

Table 6. Correlations between original variables and components.

\begin{tabular}{lllllll}
\hline & \multicolumn{3}{c}{1981 S5 } & \multicolumn{3}{c}{$1986-90$} \\
\cline { 2 - 7 } & Cl & C2 & C3 & Cl & C2 & C3 \\
\hline APR & 0.85 & - & - & 0.98 & - & - \\
AAP & 0.53 & - & - & -0.58 & - & - \\
WR & - & 0.19 & - & - & 0.21 & - \\
AW & - & -0.99 & - & - & 0.32 & - \\
LCR & - & -0.70 & - & - & 0.94 & - \\
MPR & - & - & -0.87 & - & - & -0.86 \\
I & - & - & -0.57 & - & - & -0.50 \\
FWRLR & - & - & -0.32 & - & - & -0.30 \\
\% of variance & 34.7 & 25.8 & 24.3 & 32.6 & 24.3 & 20.3 \\
\hline
\end{tabular}


Table 7. Estimated results for periods before and after Spanish accession to the

EC*

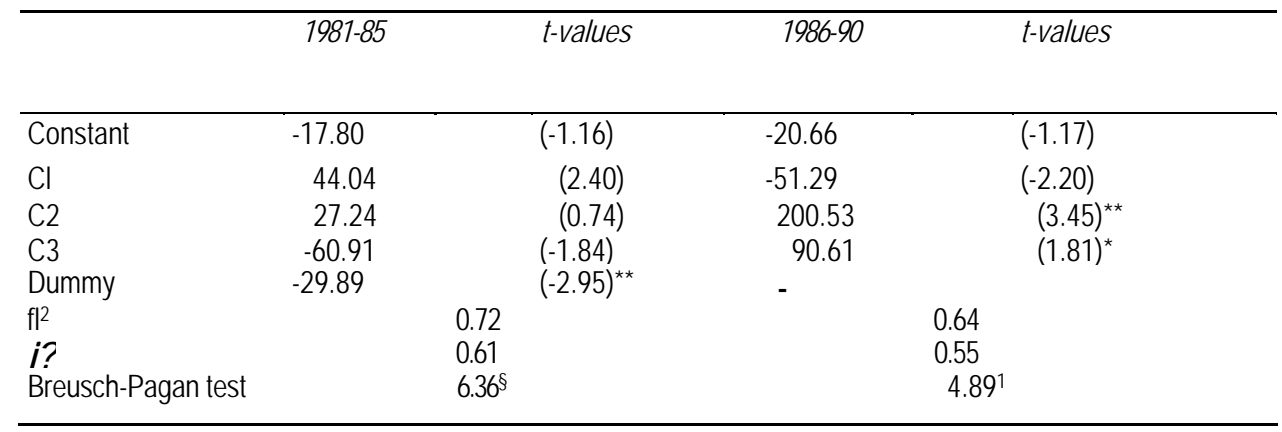

* The dependent variable is the differential shift from shift-share analysis.

* Indicates signiñcance at the $10 \%$ level.

Indicates signifícance at the $5 \%$ level. ${ }^{5}$ Critical

valué is $9.49 .{ }^{11}$ Critical valué is 7.81 .

was added in this period. It has been called 'regional policy' and takes valué 1 in those regions in which the Spanish government invests more money for development (Andalucía, Castilla-León, Galicia and Extremadura). With the exception of Andalucía, food industries growth was negative, so the sign of this dummy variable is also negative. The agricultural sector composite variable $(\mathrm{Cl})$ had a positive sign. In this period, this variable is highly correlated with agricultural production and its variation over the period considered. Cataluña and Andalucia presented high and positive valúes in those two variables, so the sign of $\mathrm{Cl}$ is positive and significant. Labour costs are not significant in explaining food industries growth rate in each región. Finally, regional economic development (C3) has a negative sign. This variable was negatively correlated with market potential, food wholesaler and retailer licences and per capita income. So, before joining the $\mathrm{EC}$, food industries had a more important relative growth in most developed regions.

The situation has changed since 1986. The economic growth and the accession to the EC allowed a redistribution of national welfare to less developed regions. Funds were directed to regional development favouring rural áreas. National links between agriculture and food industries have been reinforced. Rural development has been based, in many regions, on developing food industries to compénsate for the reduction of agricultural prices imposed by the Common Agricultural Policy. In the estimated equation for that period, composite variable $\mathrm{Cl}$ is negatively related to the relative growth of the food industries, which means that variation of agricultural production has been a key factor for the development of food industries. Food industries have become more specialized as is indicated with the positive sign of composite variable $\mathrm{C} 2$. Finally, the relative growth of food industries has been more important in less developed regions during this period.

Both models were tested for heteroskedasticity. The Breusch-Pagan test was used. In both cases the nuil hypothesis of homoskedasticity could not be rejected at the $5 \%$ level of significance. 


\section{Conclusions}

Food processing industries are one of the most important sectors in Spain. During the last year, this sector has been a key factor in promoting regional development in Spain. It has tried to take advantage of the value added generated from these industries as a means to compénsate for rural population losses owing to decreasing agricultural prices resulting from the reform of the Common Agricultural Policy. In this paper, some of the main characteristics of this sector and their contribution to regional development have been analysed. Factors affecting the location of food industries and changes taking place after accession to the EC have been studied.

Before j'oining the EC, food processing industries tended to be located near big urban áreas. Improvements in communication infrastructure, the migration process to urban áreas, the higher income level in these áreas as well as the location of large distribution chains in the main towns are some of the reasons explaining the relative growth of food industries in Spanish regions. Most of these phenomena are associated with the Spanish economic crisis at the beginning of the 1980s.

The entry of Spain into the EC has accelerated some changes, which were partially related also to the economic development that took place in the second half of the 1980s. The development of sustainable agriculture, the industrial concentration in urban áreas and its consequences on the environment and the existence of interregional as well as intraregional development imbalances have opened up new prospects for rural development with agrofood industries playing an important role. New investments have been undertaken in less developed regions financed, to a great extent, by EC structural funds. Furthermore, to be more competitive and to increase Spanish food exports, it is necessary to reduce costs. The increasing vertical integration between agriculture, food industries and food distribution, and horizontal concentration have stimulated the growth of food industries in áreas of agricultural production where a new part-time «griculture is now developing.

\section{References}

Bueno, J. and Ramos, A. 1989 La industria alimentaria en España (Madrid: Bolsa de Madrid).

Caja Laboral Popular 1987 El sector agroalimentario en País Vasco y Navarra (San Sebastián: Diputación Foral de Guipúzcoa). De Haro, T. and Titos, A. 1983 El complejo de producción agroalimentaria, Papeles de Economía Española, 16:22-36.

Fernández, D. and Ruesga, S. 1984 La industria alimentaria y su futuro inmediato en España, Economia Industrial, 235: 59-77. Gil, J. M. and Pérez y Pérez, L. 1992 Regional development and agrofood industry in Spain, MEDIT, Rivista di Economia, Agriocoltura e Ambiente, 3(4): 38-44. Instituto Nacional de Estadística (INE) Encuesta Industrial (severalyears) (Madrid: Ministerio de Economía). Instituto Nacional de Estadística (INE) \{several years) Contabilidad Regional (Madrid: Ministerio de Economia). Jordana, J. 1983 La industria alimentaria española, Papeles de Economia Española, 16: 183-202. Jordana, J. and Pulgar, J. 1980 Situación y problemas actuales de la Industria Agroalimentaria, Revista de Estudios Agro-Sociales, 111: 35-61. Rapún Gárate, M. and Pérez y Pérez, L. 1990 Agricultura e industria alimentaria en el Valle Medio del Ebro, in J. M. Serrano (ed.), Estructura Económica del Valle Medio del Ebro (Madrid: Espasa-Calpe), 197-

227. Rodríguez-Zúñiga, M., Ruiz, J. and Soria, R. 1982 Aproximación al análisis del sector agro-industrial en Castillay León (Salamanca: Caja de Ahorros de Salamanca). Sanz, J. 1989 Caracterización estructural de la industria agroalimentaria de primera transformación en areas urbano-industriales: el caso de la Comunidad de Madrid, Revista de 
Estudios Agrosociales, 141: 113-155. Sequeiros, J. 1983 El sector agromarindustrial en Galicia: perspective de desarrollo e integración (Santiago de Compostela: Junta de Andalucía). Terrasi, M. P. 1984 Factors affecting the location of food processing industries in Italy, Proceedings of the IV European Congress of Agricultural Economists, Working Group B2 (Agricultural markets and prices) Kiel, Germany, 33-46. 